\title{
A novel protein-coding ORF72.2 gene was identified from Marek's disease virus strain CVI988
}

\author{
Mingxing Tian', Yang Zhao', Min Shi', Yan Lin', Nianli Zou', Ping Liu ${ }^{1,2}$, Xintian Wen ${ }^{1,2}$, Sanjie Cao ${ }^{1,2}$, \\ Yong Huang ${ }^{1,2^{*}}$
}

\begin{abstract}
Marek's disease is a highly contagious disease of poultry characterized by rapid-on set of T-cell lymphomas, which is caused by Marek's disease virus (MDV), but its pathogenic mechanism is still not very clear. Recently, some new progress were achieved in molecular character of MDV. Along with the genomic sequencing of MDV serotype 1 , some novel open reading frames (ORFs) were predicted, and ORF72.2 was one of them which have no homologues in other MDV serotypes or in other alphaherpesvirus. In the study, ORF72.2 was firstly identified as a proteincoding gene by the method of reverse transcription polymerase chain reaction (RT-PCR), western blotting and indirect immunofluorescence assay. This study paved the way to conduct further studies to determine whether ORF72.2 plays a role in MDV replication and pathogenicity.
\end{abstract}

\section{Findings}

Marek's disease (MD) is a highly contagious disease of poultry characterized by mononuclear cellular infiltrates in peripheral nerves and various other organs and tissues including iris and skin. The disease has a worldwide distribution and remains a major concern for the poultry industry even though vaccines are used widely today [1]. The causative agent of the disease is Gallid herpesvirus 2, which is also called Marek's disease virus (MDV) serotype 1. This virus is an alphaherpesvirus of the genus Mardivirus [2], which also includes the antigen-related Meleagrid herpesvirus 1 (HVT), a strain used widely as a vaccine against MD since the late 1960s [3,4], as well as Gallid herpesvirus 3 (MDV-2), which includes apathogenic strains some of which are used as live vaccines against MD [5].

The complete genomic sequence of the MDV-1 vaccine strain CVI988 was determined in 2007 which consisting of 178311 bp with an overall gene organization identical to that of the oncogenic strains such as GA, RB1B, Md5, Md11, 584A. The genome of

\footnotetext{
* Correspondence: hyong601@163.com

${ }^{1}$ College of Veterinary Medicine, Sichuan Agricultural University, Ya'an,

Sichuan, 625014, PR China

Full list of author information is available at the end of the article
}

CVI988-BAC contains over 478 ORFs encoding proteins with more than 50 amino acid (aa) residues [6]. Among the ORFs, the putative functions of some ORFs were predicted based on the comparison with homologous genes of other alphaherpesvirus whose functions had already been well known $[7,8]$, however, some ORFs are found to have no homologues in other alphaherpesvirus. ORF72.2 in vaccine strain CVI988 was one of those ORFs and consists of 621 nucleotides, encoding 206 aa residues. In this study, the ORF72.2 protein was firstly indentified, expressed and localized in cell by western blotting and immunofluorescence assay, which laid the foundation for the study of pathogenic mechanism of MDV.

The MDV CVI988 strain used in this study was grown in chicken embryo fibroblast (CEF) cells. Cell cultures were maintained in modified Eagle's medium (MEM) supplemented with $10 \%$ fetal bovine serum (FBS), $0.22 \%$ $\mathrm{NaHCO} 3,100 \mathrm{IU} / \mathrm{ml}$ penicillin and streptomycin [9]. The RNA was extracted using RNAprep pure Cell Kit (TIANGEN, Beijing, China) from normal CEFs and MDV-infected CEFs at $24 \mathrm{~h}, 48 \mathrm{~h}, 72 \mathrm{~h}, 96 \mathrm{~h}$ postinfection. Then a pair of primers were designed based on the bioinformatics analysis (Primer Premier 5.0 software) of the ORF72.2 gene and used to amplify a 590
C Biomed Central

C 2010 Tian et al; licensee BioMed Central Ltd. This is an Open Access article distributed under the terms of the Creative Commons Attribution License (http://creativecommons.org/licenses/by/2.0), which permits unrestricted use, distribution, and reproduction in any medium, provided the original work is properly cited. 
base pair (bp) fragment spanning nt 22 through 612 of ORF72.2 gene, and the amplification was performed with reverse transcription polymerase chain reaction (RT-PCR) (Figure 1). The sequences of the primers used for this purpose were R1: 5'-CCGGAATTCCCTGA TACTGCTAAGAGATCAC-3' with EcoRI site (underlined) and R2: 5'-CCCAAGCTTCGTATACAGCCGAA CATAAT-3' with Hind III site (underlined). The result showed that the ORF72.2 gene was successfully amplified from MDV-infected CEFs by RT-PCR at all time points tested, which suggested that the ORF72.2 gene was transcribed persistently in middle and late time of viral infection.

The amplified product was cloned into pET32 (+) plasmid to get a recombinant plasmid named pET32ORF72.2. Escherichia coli BL21 (DE3) were transformed with the recombinant plasmid, and protein expression was induced with $1 \mathrm{mM}$ IPTG at $37^{\circ} \mathrm{C}$ for $4 \mathrm{~h}$. The bacterial proteins were analyzed by $12 \%$ SDS-PAGE under denaturing conditions. Protein bands were visualized after staining with $0.1 \%$ Coomassie blue R250, and the protein concentration was determined using program BandScan 5.0 [10]. The recombinant ORF72.2 protein with molecular weight of about $41 \mathrm{KDa}$ by SDS-PAGE

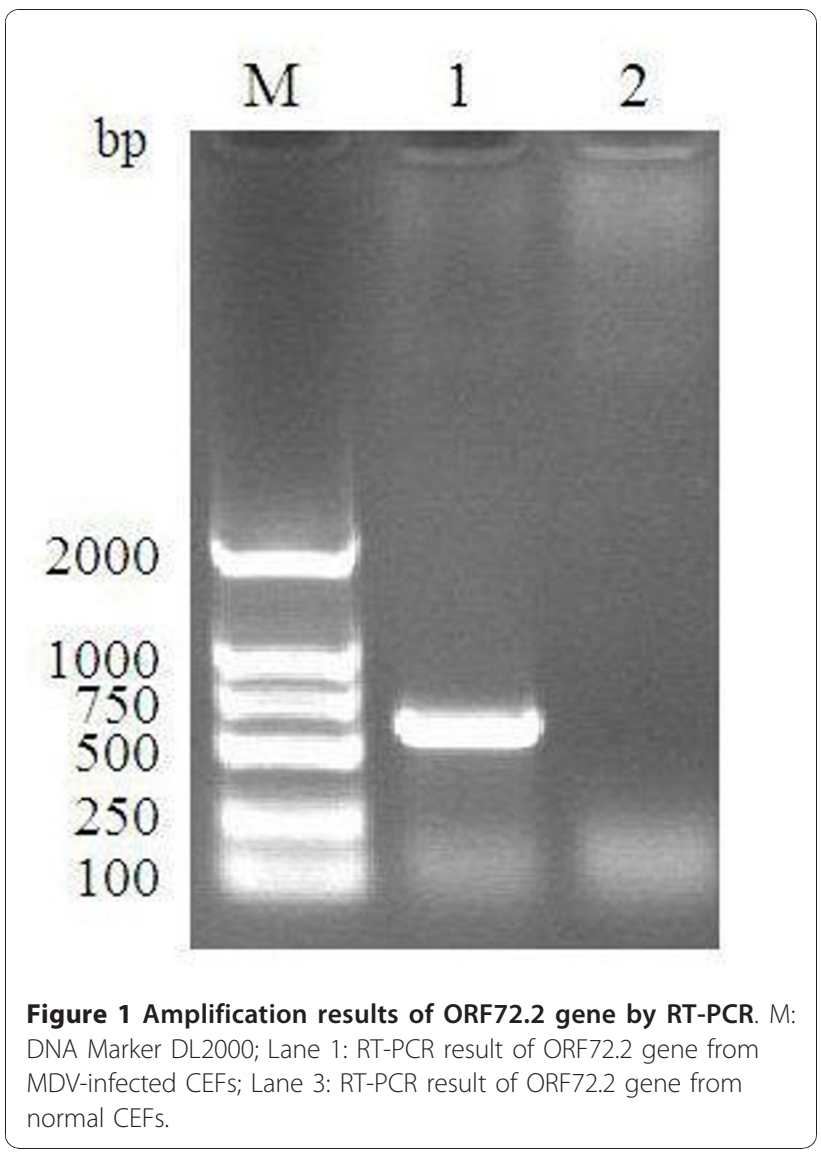

analysis was successfully expressed in the transformed cells (Figure 2).

The expressed recombinant ORF72.2 protein was trapped in inclusion bodies. The cells were harvested by centrifugation and resuspended in Phosphate-Buffered Saline (PBS) ( $\mathrm{pH} 8.0)$ containing lysozyme $(0.1 \mathrm{mg} / \mathrm{mL})$ by $1 / 10(\mathrm{v} / \mathrm{v})$, after ice bathing for $30 \mathrm{~min}$, the suspension were sonicated and centrifuged at $12000 \mathrm{~g}$ for $10 \mathrm{~min}$. The pellets were homogenated and washed with washing buffer [50 mM Tris- $\mathrm{HCl}$ (pH 8.0), 1 mM EDTA, 0.2\% Triton $\mathrm{X}-100,2 \mathrm{M}$ urea] for three times at $10 \mathrm{~min} /$ times and centrifugated at $12000 \mathrm{~g}$ for $10 \mathrm{~min}$. The pellets were dissolved by denaturation buffer $[50 \mathrm{mM}$ Tris- $\mathrm{HCl}(\mathrm{pH}$ 8.0), $2 \mathrm{mM}$ 2-mercaptoethanol, $8 \mathrm{M}$ urea] and supernatant were collected after centrifugation. The supernatant was treated with renaturation buffer $[50 \mathrm{mM}$ Tris- $\mathrm{HCl}$ ( $\mathrm{pH} 8.0), 0.1 \mathrm{mM}$ oxidized glutathione, $1 \mathrm{mM}$ reduced glutathione, $0.5 \mathrm{M}$ urea] for overnight at $4{ }^{\circ} \mathrm{C}$ and filtrated through $0.45 \mathrm{uM}$ filtration membrane. Then the solution was purified on a column packed with Ni-NTA His Bind superflow according to the manufacture's instruction (Merck, Darmstadt, Germany). Bound protein fractions were pooled, dialyzed and concentrated, and the protein expression yield was analyzed by Bradford assay [11]. For the purified fusion protein, a single objective band was detected by SDS-PAGE (Figure 2).

For production of chicken antiserum against MDV, 1-day-old specific pathogen-free (SPF) chicken were injected intraperitoneally (i.p) with $0.2 \mathrm{ml}$ of $\mathrm{MDV}$ CVI988 (Intervet) containing 4000 plague forming unit (PFU), and booster injection was done at days 10 using the same method [12]. Two weeks after immunization, the blood was harvested from jugular vein and the antiserum was isolated. The serum of non-immunized chicken was also isolated as control.

For production of rabbit antiserum against recombinant ORF72.2 protein, New Zealand white rabbits were first immunized intradermally with $1 \mathrm{mg}$ purified recombinant protein mixed with an equal volume of complete Freund adjuvant (Sigma, Shanghai, China) and with purified recombinant protein mixed with an equal volume of incomplete Freund adjuvant on days 14 and 28 later as booster injection, respectively. The serum was collected at 10 days after the final booster injection. The antiserum was purified using ammonium sulfate precipitation and High-Q anion-exchange chromatography [13].

To testify indirectly whether the ORF72.2 protein can be expressed in chickens after MDV CVI988 infection, the chicken antiserum against MDV produced above was used to make a western-blot. Firstly, purified recombinant proteins were separated by SDS-PAGE, and then the proteins were transferred to Polybinylidene Difluoride (PVDF) membrane with $0.25 \mathrm{uM}$ pore size (Millipore Corp., USA) at $15 \mathrm{~V}$ for $1.5 \mathrm{~h}$. Then the 


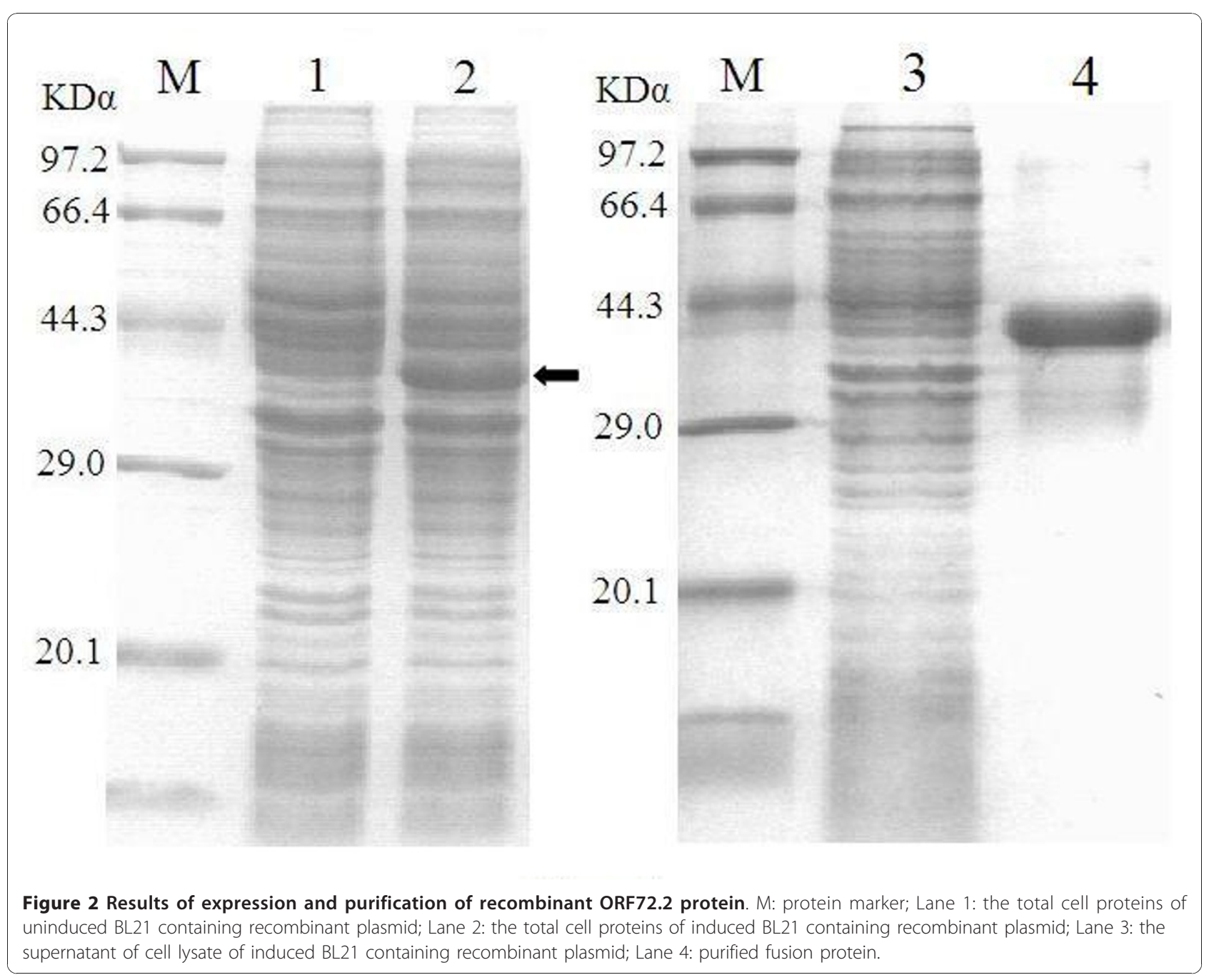

membrane was blocked for 90 min with milk buffer [20 $\mathrm{mM}$ Tris- $\mathrm{HCl}$ (pH8.0), $150 \mathrm{mM} \mathrm{NaCl}, 0.05 \%$ Tween 20, $5 \%$ skinned dry milk] at $37^{\circ} \mathrm{C}$ and washed with Tris-Buffered Saline with Tween 20 (TBST) buffer [20 mM Tris$\mathrm{HCl}$ (pH8.0), $150 \mathrm{mM} \mathrm{NaCl}, 0.05 \%$ Tween20] for three times. Then the membrane was incubated with chicken antiserum diluted 1:50 in 0.1\% Bovine Serum Albumin (BSA)/PBS for $60 \mathrm{~min}$ at $37^{\circ} \mathrm{C}$ and washed with TBST, and then incubated with horseradish peroxidase (HRP)labeled rabbit-anti-chicken IgG (Zhongshan Goldenbridge Biotechology co., Ltd, Beijing, China) for $60 \mathrm{~min}$ at $37^{\circ} \mathrm{C}$. Target proteins were visualized using 3, 3'-Diaminobezidine (DAB) (TIANGEN, Beijing, China). The result of western blotting showed the fusion protein can react positively with chicken antiserum against MDV (Figure 3), which proved that the ORF72.2 protein can be expressed in chickens after MDV infection and an immune response can be induced by natural ORF72.2 protein, but band line of western blotting was light, implying the expression level or immunogenicity of natural ORF72.2 protein in chicken after MDVs infection is weak.

To further confirm the existence of ORF72.2 protein in MDV-infected CEFs, indirect immunofluorescence studies were performed with the rabbit antiserum against recombinant ORF72.2 protein produced above. CEFs were mock-infected or infected with MDV and were collected at $72 \mathrm{~h}$ post-infection when cytopathogenic effect (CPE) had just appeared. Cells on coverslips were fixed with $4 \%$ cold paraformaldehyde for overnight at $4{ }^{\circ} \mathrm{C}$ and treated with $3 \%$ BSA to block the nonspecific staining, and then permeabilized with $0.2 \%(\mathrm{v} / \mathrm{v})$ TrionX-100 in PBS for $20 \mathrm{~min}$ at room temperature. The samples were incubated with rabbit antiserum against recombinant ORF72.2 protein diluted in 1:100 for overnight at $4^{\circ} \mathrm{C}$ and washed with TBST for three times, and then incubated with fluorescein isothiocyanate (FITC)-conjugated sheep-anti-rabbit IgG (Zhongshan Goldenbridge Biotechology co., Ltd, Beijing, China) for $1 \mathrm{~h}$ at $37^{\circ} \mathrm{C}[14,15]$. The result showed that specific 


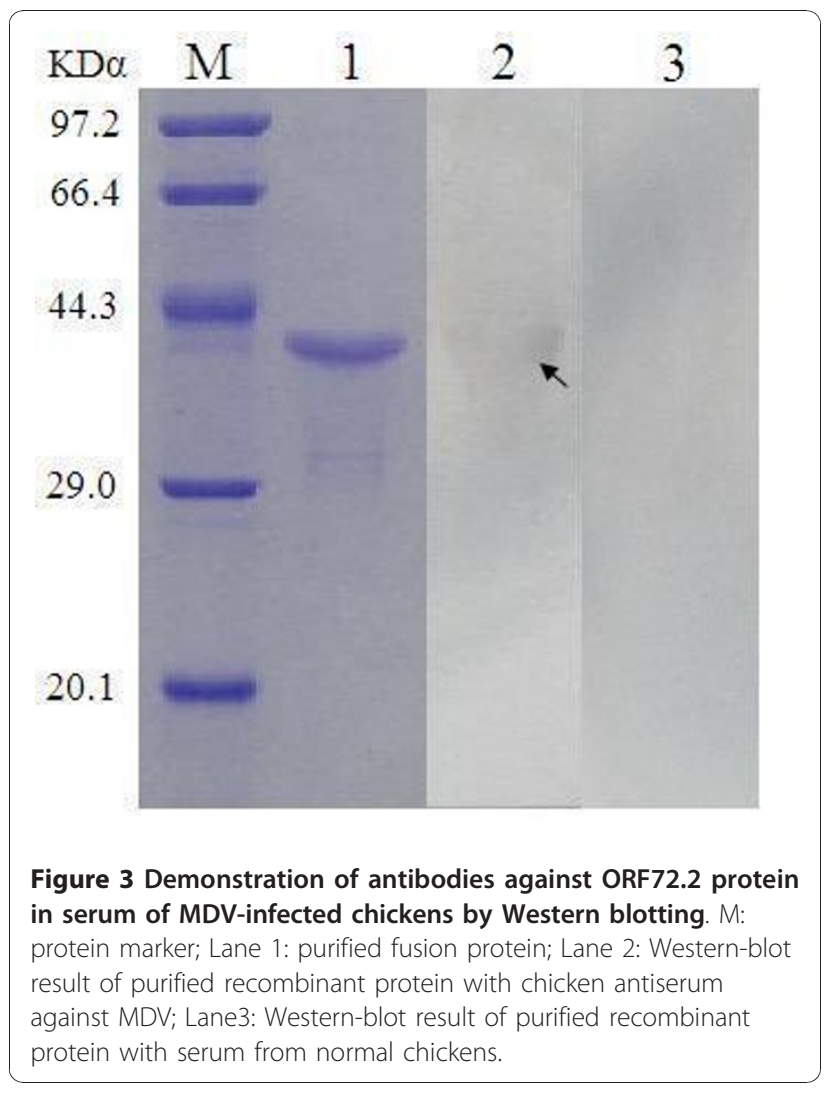

fluorescence appeared in cytoplasm and nuclear membrane region of infected cells at $72 \mathrm{~h}$ post-infection (Figure 4).
In this study, ORF72.2 gene was identified from MDV CVI988 in the level of transcription and expression. Firstly, mRNA was extracted from CEFs infected by CVI988 using RT-PCR, which proved that ORF72.2 gene is successfully transcribed in infected cells. Secondly, the highly antigenic region of ORF72.2 gene was successfully cloned and expressed in an E. coli pET32 $(+)$ expression system. Thirdly, the existence of antibodies against natural ORF72.2 protein in chickens after MDV infection was verified by western blotting using recombinant ORF72.2 protein as the antigen. Meanwhile, the existence of ORF72.2 protein in MDVinfected CEFs was further verified by immunofluorescence assay using rabbit antiserum against recombinant protein. Generally, natural ORF72.2 protein was found in MDV infected cells and natural antibodies against ORF72.2 protein can be detected in chicken after MDV infection, all this proved that ORF72.2 gene is really a novel protein-coding gene of MDV.

In addition, bioinformatics analysis of the complete genomic sequence of MDV revealed that ORF72.2 gene existed both in mild virulent MDVs (such as CU-2) and high virulent MDVs (such as GA, RB1B, MD5, MD11, 584A), but it was only found in MDV serotype 1 and its homologous gene was not identified in MDV serotype 2 and 3 or in other alphaherpesvirus. Deduced amino acid sequence of ORF72.2 was searched for the existence of protein motifs in the PROSITE pattern database and the function of this protein was searched too, but no available database and protein motifs could be found.
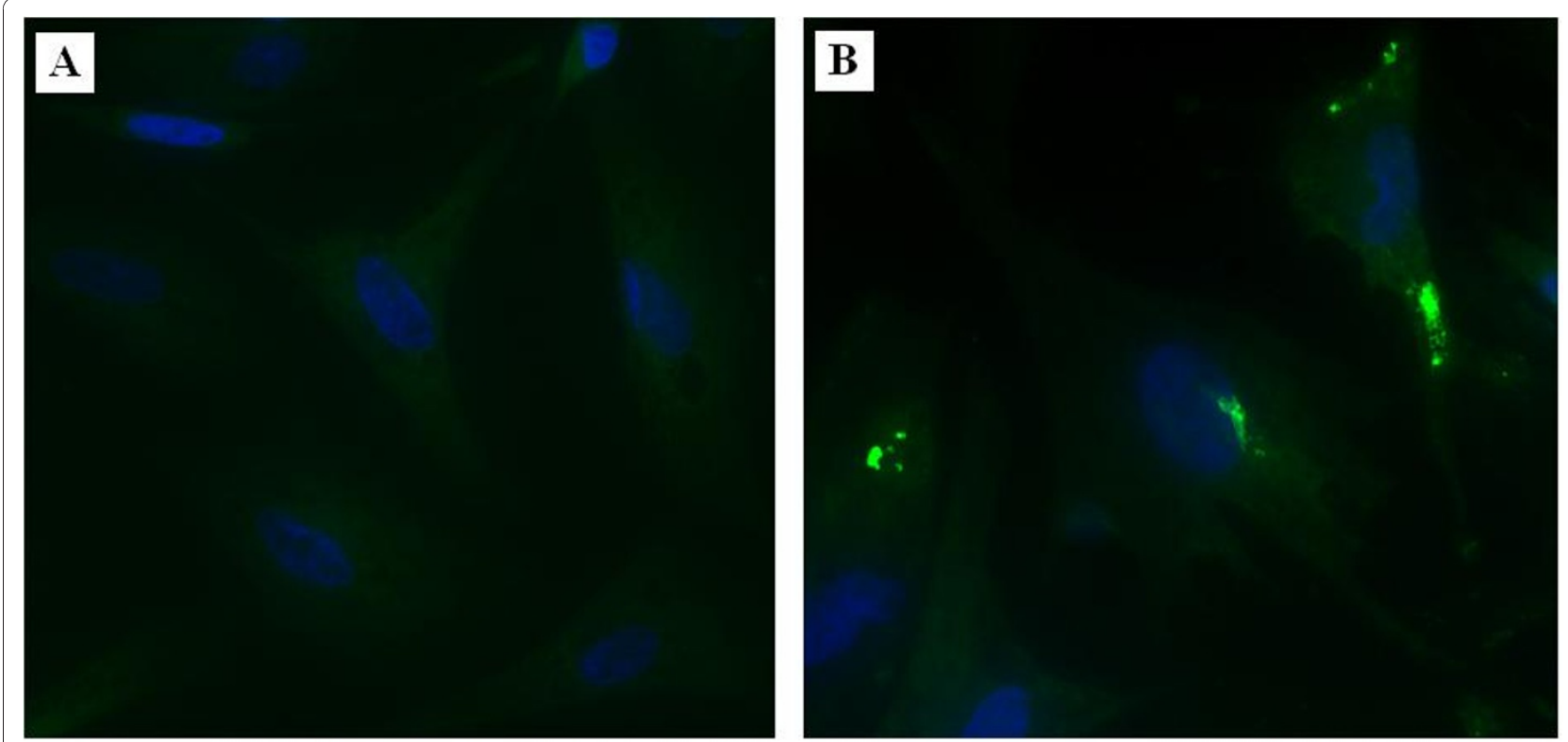

Figure 4 Detection of ORF72.2 protein by immunofluorescence assay in non-infected CEFs (A) and MDV-infected CEFs (B). CEFs were incubated with rabbit antiserum against recombinant ORF72.2 protein, and subsequently stained with fluorescein isothiocyanate (FITC)conjugated sheep-anti-rabbit lgG. Nuclear were counterstained with DAPI (blue). 
In conclusion, a novel protein encoded by ORF72.2 gene was identified and verified by method of western blotting and indirect immunofluorescence assay (IFA), however, it was not really clear whether this protein is important to the replication and pathogenicity of MDV, further study should be undertaken in the following study.

\section{Acknowledgements}

The research was supported by program for Changjiang Scholars and Innovative Research Team in University (PCSIRT0848).

\section{Author details}

'College of Veterinary Medicine, Sichuan Agricultural University, Ya'an, Sichuan, 625014, PR China. 'Key Laboratory of Animal Disease and Human Health of Sichuan Province, Sichuan Agricultural University, Ya'an, Sichuan, 625014, PR China.

\section{Authors' contributions}

MT: Study design, performed the experiments, interpreted the data and wrote the manuscript. $Y Z, M S, Y L, N Z, P L, X W, S C$ and $Y H$ : helped in experiments and drafting the manuscript. All authors read and approved the final manuscript.

\section{Competing interests}

The authors declare that they have no competing interests.

Received: 7 October 2010 Accepted: 23 December 2010

Published: 23 December 2010

\section{References}

1. Saif YM, Barnes HJ: Diseases of poultry. Ames, lowa: Blackwell Pub. Professional, 12 2008, 452-514.

2. Berger P, Adams M, Barnett O, Brunt A, Hammond J, Hill J, Jordan R, Kashiwazaki S, Rybicki E, Spence N: Virus Taxonomy. Eighth Report of the International Committee on Taxonomy of Viruses. Academic Press; 2005.

3. Witter RL: Protection by attenuated and polyvalent vaccines against highly virulent strains of Marek's disease virus. Avian Pathol 1982, 11:49-62.

4. Kawamura $\mathrm{H}$, King DJ, Anderson DP: A herpesvirus isolated from kidney cell culture of normal turkeys. Avian Dis 1969, 13:853-863.

5. Schat KA, Calnek BW: Characterization of an apparently nononcogenic Marek's disease virus. J Natl Cancer Inst 1978, 60:1075-1082.

6. Spatz S, Petherbridge L, Zhao Y, Nair V: Comparative full-length sequence analysis of oncogenic and vaccine (Rispens) strains of Marek's disease virus. Journal of General Virology 2007, 88:1080.

7. Niikura M, Liu HC, Dodgson JB, Cheng HH: A comprehensive screen for chicken proteins that interact with proteins unique to virulent strains of Marek's disease virus. Poult Sci 2004, 83:1117-1123.

8. Nishiyama Y: Herpes simplex virus gene products: the accessories reflect her lifestyle well. Rev Med Virol 2004, 14:33-46.

9. Imai K, Yuasa N, Kobayashp S, Nakamura K, Tsukamoto K, Hihara H: Isolation of Marek's disease virus from Japanese quail with lymphoproliferative disease. Avian Pathol 1990, 19:119-129.

10. Gunasekera RS, Damodaran H, Rajakarunanayake Y, Hyland K: The Significance of Linearity of Quantities in Electrophoresed and Blotted Materials Demonstrated by BandScan - an Analytical Program. Proceedings of the 2005 IEEE Computational Systems Bioinformatics Conference - Workshops IEEE Computer Society; 2005, 277-282, 277-282.

11. Bradford MM: A rapid and sensitive method for the quantitation of microgram quantities of protein utilizing the principle of protein-dye binding. Anal Biochem 1976, 72:248-254.

12. Liang P: Comparative studies on the vaccination and revaccination of Marek's disease. Yangzhou University, Veterinary College; 2005.

13. McGuire JM, Douglas M, Smith KD: The resolution of the neutral N-linked oligosaccharides of $\mathrm{lgG}$ by high $\mathrm{pH}$ anion-exchange chromatography. Carbohydr Res 1996, 292:1-9.
14. Xie W, Cheng A, Wang M, Chang H, Zhu D, Luo Q, Jia R, Chen X: Expression and characterization of the UL31 protein from duck enteritis virus. Virol J 2009, 6:19.

15. Xiang J, Ma G, Zhang S, Cheng A, Wang M, Zhu D, Jia R, Luo Q, Chen Z, Chen $X$ : Expression and intracellular localization of duck enteritis virus pUL38 protein. Virol J 2010, 7:162.

doi:10.1186/1743-422X-7-371

Cite this article as: Tian et al: A novel protein-coding ORF72.2 gene was identified from Marek's disease virus strain CVI988. Virology Journal 2010 7:371.

\section{Submit your next manuscript to BioMed Central and take full advantage of:}

- Convenient online submission

- Thorough peer review

- No space constraints or color figure charges

- Immediate publication on acceptance

- Inclusion in PubMed, CAS, Scopus and Google Scholar

- Research which is freely available for redistribution
Ciomed Central 